

Economic Laboratory Transition Research Podgorica

\section{Montenegrin Journal of Economics}

Nguyen, M.H, Tran, T.P.T, Pham, M.V. (2021), “The Impact On Corporate Financial Leverage of the Relationship Between Tax Avoidance and Institutional Ownership: A Study of Listed Firms in Vietnam", Montenegrin Journal of Economics, Vol. 17, No. 4 (2021), 65-73.

\title{
The Impact on Corporate Financial Leverage of the Relationship Between Tax Avoidance and Institutional Ownership: A Study of Listed Firms in Vietnam
}

\section{NGUYEN MINH HA ${ }^{1}$ (Corresponding author), TRAN THI PHUONG TRANG ${ }^{2}$ and PHAM MINH VUONG ${ }^{3}$}

\begin{abstract}
1 Professor, Business and Economics Research Group, Ho Chi Minh City Open University, e-mail: ha.nm@ou.edu.vn 2 Postgraduate School, Ho Chi Minh City Open University

3 Faculty of Accounting and Auditing, Ho Chi Minh City Open University
\end{abstract}

\section{ARTICLE INFO}

Received October 19, 2020

Revised from November 21, 2020

Accepted December 23, 2020

Available online December 15, 2021

JEL classification: G23, G32, H26

DOI: $10.14254 / 1800-5845 / 2021.17-4.6$

Keywords:

Institutional ownership,

leverage,

tax avoidance,

Vietnam

\begin{abstract}
This study analyzes the impact of tax avoidance and institutional ownership on the business leverage ratio. Businesses evade taxes to gain the benefits of increasing current profits and reducing their dependence on external funding. A review of capital structure theo$r y$, the trade-off theory of capital structure, the pecking order theory, and studies around the world initially show the impact of the correlation between tax avoidance and institutional ownership on business borrowing and solvency. The paper employs a GLS (Generalized least squares) model to conduct analysis for 207 Vietnamese firms listed on the Ho Chi Minh Stock Exchange (HOSE), with a total of 1,863 observations over the period 2008-2016. The empirical results confirm a negative correlation between tax avoidance activities and the business leverage ratio. However, there is not enough evidence to support a correlation between organizational ownership and the business leverage ratio.
\end{abstract}

\section{INTRODUCTION}

Tax avoidance is the legal use of rules in the current tax regime to reduce the tax liability. Businesses are expected to participate in tax avoidance with the aim of increasing current profits (Noor, Mastuki, and Bardai, 2009; Chung, Firth, and Kim, 2002). It is also possible to view tax avoidance as a way to obtain temporary capital for businesses. As a result, businesses with higher tax avoidance need less external funding; thus, it helps in reducing debt and leverage. Tax avoidance is also considered a legal approach for businesses to take in availing themselves of credit that will enable them to reduce borrowing, this is consistent with Myers and Majluf's pecking order theory (1984). Some empirical studies show that when 
companies employ tax shields or avoid tax, they take on less debt (Graham and Tucker, 2006). Yet tax avoidance can also be a sign of a business manager's willingness to pursue personal goals, which might involve agency costs. An increase in institutional ownership is believed to boost the quality of corporate governance, thereby limiting the correlation between these two factors (Desai and Dharmapala, 2004). This initially shows the impact of the correlation between tax avoidance and institutional ownership on business borrowing and solvency. The number of papers on the relationship between these factors that examine Vietnamese business is still very limited. Hence, the main objective of this study is to understand the impact of tax avoidance and institutional ownership on the financial leverage of listed firms on the Ho Chi Minh Stock Exchange (HOSE). We focus on answering the following question: How does tax avoidance and institutional ownership affect the financial leverage of Vietnamese businesses? To be more specific, these two aspects are at core of the paper: (1) How does tax avoidance and institutional ownership affect the financial leverage of businesses? (2) How can businesses take advantage of tax avoidance and institutional ownership to influence their financial leverage, contributing to the adjustment of debt policy in accordance with performance targets?

The study sample consists of Vietnamese enterprises listed on the HOSE in the period 2008-2016. To ensure uniformity across the sample, we omit companies in finance and insurance, banking, and real estate, companies whose financial information was not disclosed during the research period, and companies that suffered losses at the end of the financial year. In addition, to increase the reliability of the research, some other control variables, based on suggestions from other studies, with an impact on business leverage are added to the model. The paper uses secondary data from the financial statements of 207 businesses, totaling 1,863 observations.

\section{LITERATURE REVIEW}

\subsection{Definition of Tax Avoidance}

Tax avoidance is the subject of many studies. For example, tax avoidance refers to efforts to reduce accounting profit before tax calculated in dollars (the currency used in the study) (Hanlon and Heitzman, 2009). According to Hanlon and Heitzman (2009), the difference between taxable income and accounting income is affected by the financial accounting standard, following the format prescribed in GAAP (generally accepted accounting principles) and tax regulations. Tax avoidance is also defined as the transfer of value from the government to shareholders (Desai and Dharmapala, 2009). In other words, tax avoidance is the act of legally taking advantage of the current tax provisions to reduce the amount of tax to be paid. In general, tax avoidance is traditionally perceived as transferring financial resources from the government to shareholders, thus increasing the company's after-tax value. However, tax avoidance does not always increase corporate value after tax, as in some cases it can reduce company value, associated with costs directly related to firm tax planning costs, such as adaptation costs and agency costs (Wang, 2010).

Studies have raised the question: why do some businesses avoid taxes more than others? Researchers interpret this course of action from different perspectives. Explanations are based on the characteristics of the business, the field of operation, the size, the age of the business, etc. Others, such as Graham and Tucker (2006) and Desai and Dharmapala (2004, 2009, 2011), base their arguments on the ownership structure and organizational characteristics.

Increasing tax avoidance leads to two perspectives on the consequences of this activity. First, tax avoidance is inferred as increasing other tax incentives; second, this involves agency costs, which serve as a tool for covering up the difference between accounting and real profits. In the first perspective, according to Graham and Tucker (2006), tax avoidance is the act of taking advantage of tax incentives, such as using debt. This view suggests that tax avoidance can be a substitute for debt use, so there should be a negative relationship with the cost of debt, and this relationship is stronger with a higher proportion of institutional ownership (Lim, 2011). The second perspective underlines the correlation between tax avoidance and agency costs, and tax avoidance can be used by managers as a cover for discrepancies in real profits. 


\subsection{Tax Avoidance and Tax Evasion}

Before we discuss previous research on tax avoidance behavior, it is necessary to confirm the difference between tax avoidance and tax evasion. The difference is primarily based on the legitimacy of taxpayer behavior (Sandmo, 2004). Tax evasion, when the taxpayer intentionally fails to report taxable income, is against the law. When evading taxes in this way, taxpayers are concerned about the possibility that their actions will be discovered. Tax avoidance, in contrast, is an activity within the framework of tax laws. It is the use of tax law provisions to reduce tax liability by converting operational income into capital income to obtain lower tax rates.

Based on these definitions, an intimate relationship between tax avoidance and the entity's financial policy should be considered. Financial policy is used to determine how capital can be increased to finance business activities. This is a job that is of the greatest interest to business and is also an area of great academic interest, with a range of related theories.

\subsection{Related Theories}

In 1958, Modigliani and Miller proposed the theory of a company's capital structure both with and without a tax effect. In the absence of a tax effect, the theory of the capital structure of a company suggests that there is no difference in the value of firms that do and do not borrow; in other words, the financial structure does not affect the value of the company. In addition, in the absence of a tax, the required return on equity is positively related to the amount of leverage used. With a tax effect, the value of a leveraged firm is equal to the value of the unlevered firm plus the present tax shield, and the required return on equity also increases with increasing leverage. The theory on a firm's capital structure (Modigliani and Miller, 1958) is employed in this study to explain why businesses do not use the maximum debt, taking advantage of a tax shield.

The trade-off theory of capital structure, which originated in the research of Kraus and Litzenberger (1973), explains why businesses are often financed with a combination of debt and equity. This trade-off theory proposes that businesses cannot fully finance debt because, in addition to existing tax shield grants, the use of debt financing incurs a lot of cost, including both the direct and indirect costs of bankruptcy. With every additional percentage of debt, whereas the benefit of a tax shield increases, so does the cost of financial exhaustion, which could reach a point where the benefit from the tax shield is no longer greater than the cost of financial exhaustion, in which case the reliance on debt is no longer beneficial for businesses. For this reason, companies always seek to optimize their total business value based on this equilibrium principle, to determine how much debt and equity should be used.

Tax avoidance also arises from information asymmetry between the management and the owner. Jensen and Meckling (1976) introduced the concept of agency costs as an aggregate of the costs in a contract in which a representative (or agent) is hired to act on the behalf of the owner. Based on the distinction between ownership and stewardship at companies that causes information asymmetry, managers often have greater access to the true value of assets, potential, and risk of the company than the shareholders. In addition, business decentralization might cause problems, as managers, who directly run business activities, can choose the course of action to maximize their own self-benefit. In brief, due to the asymmetric information conditions, managers can make decisions that harm the interests of investors. In this study, agency costs arising from information asymmetry explain how managers can use tax avoidance as a means of personal gain, which, in turn, leads to the risk of reducing corporate credit and higher debt costs. Therefore, businesses with great control by institutional shareholders, in theory, can reduce the agency cost problem, as business management is required to be more transparent, which mitigates the abuse of tax avoidance.

Another related theory is the pecking order theory (Myers and Majluf, 1984). In this theory, also known as pecking order model, Myers and Majluf (1984) argue that firms prefer internal sources of financing. Businesses only turn to external funding after the exhaustion of internal sources. Also, according to Myers and Majluf (1984), the priority, in descending order, for sources of corporate funding is as follows: (1) retained earnings, (2) direct borrowing, (3) convertible debt, (4) ordinary shares, (5) non- 
convertible preferred shares, and (6) convertible preferred shares. In this study, the pecking order theory explains why businesses prefer to use internal funding over debt, and if tax avoidance provides a source of financing other than debt, then businesses will consider taking advantage of it.

\subsection{Research Hypotheses}

\subsubsection{Hypothesis on the Correlation between Tax Avoidance and the Leverage Ratio}

Previous studies present two contradictory viewpoints on the relationship between tax avoidance and financial leverage. Harrington and Smith (2012), underpinned by the trade-off theory of capital structure, suggest that firms engaged in tax avoidance are more willing to maintain high leverage, implying a positive correlation between them. However, a larger number of studies suggest that tax avoidance is negatively correlated with corporate financial leverage (Graham and Tucker, 2006; Lim, 2010; Wang et al., 2018). Therefore, we propose our first hypothesis as follows:

H1: Tax avoidance is negatively correlated with the business leverage ratio.

\subsubsection{Hypothesis on the Correlation between Institutional Ownership and the Leverage Ratio}

Graham and Tucker (2006) show that tax avoidance helps businesses to increase financial flexibility, reduce the use of debt, improve their credit rating, and thereby reduce debt costs. Desai and Dharmapala (2004), with their theoretical model of management decisions in tax avoidance, believe that institutional owners often have a greater impact on corporate governance because of their large capital contribution, which can reduce agency costs and the ability of managers to avoid taxes for the purpose of diverting profits. These two studies suggest that institutional ownership affects the decision to use leverage indirectly through its impact on tax avoidance. If tax avoidance is one way that business can enhance their capital accumulation, reducing their dependence on debt, then, a higher level of institutional ownership is associated with lower of tax avoidance implications, leading to a higher leverage ratio. Thus, we propose our hypothesis on the correlation between institutional ownership and financial leverage as follows:

H2: The proportion of institutional ownership is positively correlated with the business leverage ratio.

\section{RESEARCH MODEL AND RESEARCH DATA}

\subsection{Research Model}

To test these two hypotheses, we use a model recommended by Harrington and Smith (2012), modified for the Vietnamese market and our research objectives. The research model is as follows:

$$
\begin{aligned}
\text { LEVERAGE }_{i, t} & =\beta_{0}+\beta_{1} \text { BTD }_{i t-1}+\beta_{2} \text { TA }_{i t}+\beta_{3} \text { INST }_{i t}+\beta_{4} R O A_{i t-1}+\beta_{5} \text { SIZE }_{i t-1}+\beta_{6} M_{i t-1} \\
& +\beta_{7} R \& D_{i t-1}+\beta_{8} P_{\text {PPE }} \text { it-1 } \\
& +\beta_{8} \text { DVFT }_{i t-1}+\varepsilon_{i t}
\end{aligned}
$$

In which:

- LEVERAGE $_{i, t}$ : The leverage ratio is calculated by dividing total liabilities by total assets

- $B T D_{i t-1}$ : Tax avoidance is measured by the difference between reported revenue and implied revenue, derived from taxes payable and the corresponding tax rate.

- $T A_{i t}$ : Business total accrual 
- INST $T_{i t}$ : Institutional ownership, measures as a percentage of shares held by large financial organizations

- $R O A_{i t-1}$ : Ratio of the return on total assets

- SIZE $_{i t-1}$ : Size of the business measured by the logarithm of total assets

- $M B_{i t-1}$ : The ratio of the market value to the book value

- $R \& D_{i t-1}$ : Research and development costs of the business

- $P P E_{i t-1}$ : A business's tangible non-current assets

- $D V F T_{i t-1}$ : Deviation from the target measured by the market leverage ratio minus the business leverage ratio

- $\beta_{0}$ : Constant term

- $\varepsilon_{i t}$ : Error term

\subsection{Research Data}

The paper uses secondary data collected from vietstock.com, including financial statements of businesses publicly listed on the HOSE in the period 2008-2016. To ensure uniformity of the data, we omit businesses with particular financial properties, such as finance and insurance firms, banks, and real estate companies, companies whose financial information was not disclosed during the study period, and businesses with a negative income tax rate. The final sample consists of 207 enterprises and a total of 1,863 observations.

\section{RESULTS ANALYSIS}

\subsection{Data descriptive}

In Table 1, the difference between reported revenue and the implied revenue derived from the tax payable and the corresponding tax rate (BTD) has an average value of VND 265.649 billion, with a maximum of VND 6,608.416 billion and minimum of VND -31.608 billion; the average business total accrual $(T A)$ is VND 28.838 billion, with a maximum of VND 27,860 billion and a minimum of VND -36,162 billion; on average, the business leverage ratio is $48.1 \%$, with a maximum of $97 \%$ and a minimum of $0.1 \%$; the average proportion of institutional ownership for businesses on the HOSE is $0.24 \%$, and some businesses have no institutional ownership.

Table 1. Descriptive statistics of the data $(N=1,863)$

\begin{tabular}{|c|c|c|c|c|c|}
\hline Variables & Unit of measurement & Mean & Maximum & Minimum & $\begin{array}{c}\text { Standard } \\
\text { deviation }\end{array}$ \\
\hline BTD & Billion VND & 265.649 & $6,608.416$ & -31.608 & 682.707 \\
\hline TA & Billion VND & 28.838 & 27,860 & $-36,162$ & $2,243.765$ \\
\hline LEVERAGE & $\%$ & 48.1 & 97 & 0.1 & 0.228 \\
\hline SIZE & Logarithm & 27.774 & 34.545 & 20.215 & 1.586 \\
\hline$I N S T$ & $\%$ & 0.241 & 30.372 & 0 & 0.732 \\
\hline$R O A$ & $\%$ & 0.115 & 0.897 & -0.255 & 0.097 \\
\hline$M B$ & Times & 1.180 & 114.590 & 0 & 2.809 \\
\hline
\end{tabular}

Note: Exchange rate: $\$ 1=23,720$ VND (31 ${ }^{\text {st }}$ March 2020)

\subsection{Correlation and VIF}

Before performing the regressions, we checked the correlation coefficients between the variables in the proposed model for the likelihood of multicollinearity (Table 2). 
Table 2. Correlation matrix

\begin{tabular}{|c|c|c|c|c|c|}
\hline & $B T D$ & TA & LEVERAGE & SIZE & INST \\
\hline BTD & 1.000 & & & & \\
\hline TA & -0.069 & 1.000 & & & \\
\hline LEVERAGE & 0.243 & -0.077 & 1.000 & & \\
\hline SIZE & 0.679 & -0.087 & 0.467 & 1.000 & \\
\hline INST & 0.037 & -0.027 & 0.025 & 0.048 & 1.000 \\
\hline
\end{tabular}

In Table 2, no pairs of variables have excessively high correlation, and the correlation coefficients are less than 0.5. Only the pair SIZE and BTD are highly correlated, with a coefficient of 0.679 . To confirm the multicollinearity in the regression model, we carried out a variance inflation factor (VIF) test. The test results are presented in Table 3.

Table 3. Variance inflation factor

\begin{tabular}{|c|c|}
\hline Variable & VIF \\
\hline SIZE & 2.30 \\
\hline BTD & 1.95 \\
\hline LEVERAGE & 1.39 \\
\hline$T A$ & 1.03 \\
\hline$I N S T$ & 1.00 \\
\hline
\end{tabular}

According to the VIF test results in Table 3, none of the variables have a VIF greater than 5, indicating that model has little likelihood of multicollinearity.

\subsection{Regression Results}

We carried out tests to determine which type of model to use: OLS (Ordinary least squares), REM (Random Effects Model), or FEM (Fixed Effects Model). Based on our result of Prob> chibar2 $=0.0000$ in the Breusch and Pagan Lagrange multiplier tests, it is better to use REM than OLS. But the results of the Hausman test, Prob> chi2 $=0.0000$, indicate that FEM is a better fit for our proposed research model. However, the study finds evidence of heteroscedasticity using the Wald test (Prob> chi2 $=0.0000$ ) and first-order autocorrelation using the Wooldridge test (Prob> $F=0.0000)$. These two defects in the model are overcome by using the GLS (Generalized least squares) method. The regression results are in Table 4.

Table 4. Regression results from the OLS, FEM, REM, and GLS methods

\begin{tabular}{|c|c|c|c|c|}
\hline & $(1)$ & $(2)$ & $(3)$ & $(4)$ \\
\hline Dependent variables & OLS & FEM & REM & GLS \\
\hline BTD & $-0.000^{* * *}$ & -0.000 & -0.000 & $-0.000^{* * *}$ \\
& $(0.000)$ & $(0.000)$ & $(0.000)$ & $(0.000)$ \\
\hline TA & 0.000 & 0.000 & 0.000 & -0.000 \\
& $(0.000)$ & $(0.000)$ & $(0.000)$ & $(0.000)$ \\
\hline \multirow{2}{*}{ INST } & 0.006 & -0.001 & 0.000 & 0.001 \\
& $(0.004)$ & $(0.003)$ & $(0.003)$ & $(0.002)$ \\
\hline \multirow{2}{*}{ ROA } & $-0.427^{* * *}$ & $-0.072^{*}$ & $-0.146 * * *$ & $-0.295 * * *$ \\
& $(0.039)$ & $(0.039)$ & $(0.037)$ & $(0.028)$ \\
\hline SIZE & $0.035^{* * *}$ & 0.004 & $0.020 * * *$ & $0.027 * *$ \\
& $(0.003)$ & $(0.005)$ & $(0.004)$ & $(0.002)$ \\
\hline MB & -0.006 & -0.001 & -0.002 & $-0.004 *$ \\
\hline
\end{tabular}




\begin{tabular}{|c|c|c|c|c|}
\hline & $(0.004)$ & $(0.003)$ & $(0.003)$ & $(0.002)$ \\
\hline$R \& D$ & $\begin{array}{l}-0.001 \\
(0.001)\end{array}$ & $\begin{array}{l}-0.000 \\
(0.000)\end{array}$ & $\begin{array}{l}-0.000 \\
(0.000)\end{array}$ & $\begin{array}{c}-0.000 \\
(0.000)\end{array}$ \\
\hline PPE & $\begin{array}{c}0.000 * * * \\
(0.000)\end{array}$ & $\begin{array}{l}-0.000 \\
(0.000) \\
\end{array}$ & $\begin{array}{c}0.000 \\
(0.000) \\
\end{array}$ & $\begin{array}{l}-0.000 * \\
(0.000) \\
\end{array}$ \\
\hline DVFT & $\begin{array}{c}0.652 * * * \\
(0.017)\end{array}$ & $\begin{array}{c}0.521 * * * \\
(0.021)\end{array}$ & $\begin{array}{c}0.557 * * * \\
(0.019)\end{array}$ & $\begin{array}{c}0.577 * * * \\
(0.015)\end{array}$ \\
\hline _cons & $\begin{array}{c}-0.670 * * * \\
(0.085)\end{array}$ & $\begin{array}{c}0.200 \\
(0.137) \\
\end{array}$ & $\begin{array}{c}-0.251 * * \\
(0.112) \\
\end{array}$ & $\begin{array}{r}-0.447 * * * \\
(0.060)\end{array}$ \\
\hline $\mathrm{N}$ & 1836 & 1836 & 1836 & 1836 \\
\hline
\end{tabular}

\subsection{The Relationship between the Business Leverage Ratio and Tax Avoidance and Institutional Ownership}

One of the two main variables in the study, tax avoidance, measures the difference between reported revenue plus implied revenue (BTD) and institutional ownership (INST), but only BTD had results that support $\mathrm{H} 1$. The regression shows a negative relationship between $B T D$ and business financial leverage (LEVERAGE) (at a significance level of 1\%), and this result is in line with that in most previous studies (Graham and Tucker, 2006, Lim, 2010; Wang et al., 2018). Therefore, H1 is confirmed, which means that enterprises in Vietnam tend to engage in tax avoidance as a means of financing rather than debt.

The positive coefficient result for the institutional ownership variable (INST) is consistent with the findings by Graham and Tucker (2006), Nguyen and Le (2017), and Desai and Dharmapala (2004) that explain the impact of institutional ownership on business financial leverage through tax avoidance. However, this result is not statistically significant., therefore $\mathrm{H} 2$ is not supported, which shows that institutional investors either are not allowed to participate or choose not to participate in the selection of firms' financial policies. In other words, institutional investors in Vietnam have a low level of participation in decisions about operational funding sources.

\subsection{The Relationship between the Control Variables and the Business Leverage Ratio}

Return on total assets (ROA) has a negative relationship with LEVERAGE, at a confidence level of 99\%. This result for the Vietnamese market is consistent with the results in Harrington and Smith (2012).

Our results imply that total business accrual (TA) and LEVERAGE have negative correlation coefficients, and this result is consistent with the research of Utkir (2012), Nguyen and Nguyen (2013), Nguyen and Phan (2019), Huu and Nguyen (2019) and Lim (2011). As explained by the pecking order theory, in the Vietnamese market, firms with surplus total accrual accumulation prefer to use equity capital over external borrowing. However, $\mathrm{P}>|\mathrm{z}|=0.305$, therefore, this result is not statistically significant.

The ratio of tangible assets of enterprises divided by total assets (PPE) and LEVERAGE have a negative relationship, at the significance level of $10 \%$. This result is the opposite of that of Frank and Goyal (2009), Quan et al. (2020), and Kayhan and Titman (2004). It means that enterprises prefer to use debt to increase their tangible assets. Because tangible assets can reduce the financial exhaustion cost, expanding them is positively correlated with business leverage.

According to research by Faulkender and Petersen (2006), Nguyen and Phan (2019), firm size $(L N(A S S E T))$ and LEVERAGE are expected to have a positive relationship. Our regression results, with the sample in Vietnam, also shows a positive correlation coefficient between them at a significance level of $1 \%$.

Deviations from targets (DVFT) is expected to be negatively correlated with LEVERAGE (Lemmon, Roberts, and Zender, 2008). The regression results in Table 4 show a coefficient of 0.577 between these 
two factors at a significance level of $1 \%$. This is contrary to the arguments in previous studies that the larger the deviation from the target that businesses have, the more debt they use.

Research and development expenses $(R \& D)$ are expected to be inversely related to LEVERAGE (Frank and Goyal, 2009). The results in this study also show the same impact, but the lack of statistical significance makes the identification of the correlation between $R \& D$ and LEVERAGE unreliable.

\section{CONCLUSION}

Using sample data on 207 Vietnamese enterprises listed on the HOSE in 2008-2016 and the GLS estimation method for the financial leverage dependent variable, we test two hypotheses on the impact on business financial leverage of relationship between tax avoidance and institutional ownership. The result of tax avoidance is negatively correlated with the leverage ratio of enterprises. At the same time, we do not find evidence to support a correlation between organizational ownership and the leverage ratio. The results also partly show the ability of businesses to influence their leverage in order to pursue strategic financial goals. In particular, improving the efficiency of operations by raising the profitability ratio of total assets helps businesses to reduce the use of financial leverage, and tax avoidance helps them lessen dependence on external borrowing. In addition, our results suggest that, when deciding between funding sources, firms in Vietnam see tax avoidance as an alternative source of funding to help them limit excessive reliance on debt.

\section{REFERENCES}

Chung, R., Firth, M., Kim, J. (2002), "Institutional monitoring and opportunistic earnings management", Journal of Corporate Finance, Vol. 8, No. 1, pp. 29-48.

Desai, M.A., Dharmapala, D. (2004), “Corporate tax avoidance and high-powered incentives", Journal of Financial Economics, Vol. 79, No. 1, pp. 145-179.

Desai, M.A., Dharmapala, D. (2009), “Earnings management, corporate tax shelters, and book-tax alignment", SSRN Electronic Journal, Vol. 62, No. 1, pp. 1-24.

Desai, M.A., Dharmapala, D. (2011), "Corporate tax avoidance and firm value", SSRN Electronic Journal, Vol. 91, No. 3, pp. 1-27.

Faulkender, M., Petersen, M. A. (2006), “Does the source of capital effect capital structure?”, Review of Financial Studies, Vol. 19, No. 1, pp. 45-79.

Frank, M. Z., Goyal, V. (2009), “Capital structure decisions: Which factors are reliably important?", Financial Management, Vol. 38, No. 1, pp. 1-37.

Graham, J.R., Tucker, A. (2006), "Tax shelters and corporate debt policy”, Journal of Financial Economics, Vol. 81, No. 1, pp. 563-594.

Hanlon, M., Heitzman, S. (2009), “A review of tax research", Working paper, Massachusetts Institute of Technology.

Harrington, C., Smith, W. (2012), "Tax avoidance and corporate capital structure", Journal of Finance and Accountancy, Vol. 11, No. 1, pp. 12-15.

Huu, T.V., Nguyen, M.H. (2019), "A Study on the Relationship Between Diversification and Firm Performance Using the GSEM Method", Emerging Markets Finance and Trade, pp. 1-23, https://doi.org/10.1080/1540496X.2019.1582413

Jensen, M.C., Meckling, W.H. (1976), "Theory of the firm: Managerial behaviour, agency costs and ownership structure", Journal of Financial Economics, Vol. 3, No. 4, pp. 305-360.

Kayhan, A., Titman, S. (2004), "Firms' histories and their capital structures", SSRN Electronic Journal, Vol. 15, No. 1, pp. 1-32.

Kraus, A., Litzenberger, R.H. (1973), “A state-preference model of optimal financial leverage”, Journal of Finance, Vol. 28, No. 4, pp. 911-922.

Lemmon, M., Roberts, M.R., Zender, J.F. (2008), "Back to the beginning: Persistence and the crosssection of corporate capital structure", Journal of Finance, Vol. 63, No. 4, pp. 1575-1608.

Lim, Y.D. (2010), "Tax avoidance and underleverage: Korean evidence", Working paper, University of New South Wales. 
Lim, Y.D. (2011), "Tax avoidance, cost of debt and shareholder activism: Evidence from Korea2, Journal of Banking \& Finance, Vol. 35, No.1, pp.456-470.

Modigliani, F., Miller, M.H. (1958), "The cost of capital, corporation finance, and the theory of investment", American Economic Review, Vol. 49, No. 4, pp. 655-669.

Myers, S.C., Majluf, N.S. (1984), "Corporate financing and investment decisions when firms have information that investors do not have", Journal of Financial Economics, Vol. 13, No. 2, pp. 187-221.

Nguyen, M.H., Le, M.T. (2017), "Impact of Capital Structure and Cash Holdings on Firm Value: Case of Firms Listed on the Ho Chi Minh Stock Exchange", International Journal of Economics and Financial Issues, Vol. 7, No. 1, pp. 24-30.

Nguyen, M.H., Nguyen, T.D.P. (2013), "Foreign Ownership Affects the performance of Listed Companies on the Vietnamese Stock Market", Review of World Economic and Political Issues, Vol. 4, No. 204, 70-80.

Nguyen, M.H., Phan, H. (2019), “The effect of institutional ownership on listed companies' performance in Vietnam", The International Journal of Economics and Business Research, Vol. 17, No. 3, 317322.

Noor, R.M., Mastuki, N., Bardai, B. (2009), "Book-tax difference and value relevance of taxable income: Malaysian evidence", Journal of Financial Reporting \& Accounting, Vol. 7, No. 1, pp. 19-40.

Quan, M.Q.B., Nguyen, M.H., Ngo, T.H.T.,2(020), "Application of an intangible asset valuation model using panel data for listed enterprises in Vietnam", Investment Management and Financial Innovations, Vol. 17, No. 1, 304-316.

Sandmo, A. (2005), "The theory of tax evasion: A retrospective view”, National Tax Journal, Vol. 58, No. 4, pp. 643-663.

Utkir, K. (2012), "The relationship of corporate tax avoidance, cost of debt and institutional ownership: evidence from Malaysia", Atlantic Review of Economics, Vol. 2, pp.1-36.

Wang, P., et al. (2018), "Property rights, tax avoidance and capital structure: Data from China stock markets", International Journal of Economics and Finance, Vol. 10, No. 11, pp. 13-27.

Wang, X. (2010), “Tax avoidance, corporate transparency, and firm value", Working paper, The University of Texas at Austin 